\title{
Sindrome mielodisplasikoa del(5q) isolatuarekin
}

\section{Myelodysplastic syndrome (mds) with isolated del(5q)}

\author{
Lide Ezenarro, Jose Ramon Furundarena, Anunciación Urquia \\ Donostia Unibertsitate Ospitaleko Hematologia Zerbitzua
}

lezenarrus@gmail.com

\section{Laburpena}

Sindrome mielodisplasikoen (SMD) artean sailkatzen da SMD del(5q) isolatuarekin, ezaugarri nagusitzat anemia, megakariozito hipolobulatuak, hezur-muineko blastoen portzentajea <\% 5 eta del(5q) alterazio zitogenetikoa dituena eta pronostiko hoberenetarikoa duena. Lan honetan bildu dira azkeneko 10 urteetan Donostia Unibertsitate Ospitalean diagnostikatu diren kasuak, eta haien datu kliniko, pronostiko eta terapeutikoak aztertu dira. Horrez gain, tratamenduren arloan SMD mota honetan lenalidomida farmakoak duen eragin postiboa eta, haren albo-ondorioak ezagututa, farmako hori komenigarria izango zaien pazienteak kontuz aukeratu behar direla ikusi da. Horretarako tratamendu-protokoloa proposatu da.

Gako-hitzak: SMD del( $5 q)$ isolatuarekin, $5 q$ - sindromea, lenalidomida

\section{Abstract}

Myelodysplastic syndrome (MDS) with isolated del(5q) is characterized by anemia, hypolobated megacaryocytes, $<5 \%$ bone marrow blast, the del(5q) cytogenetic abnormality and a good prognosis. Here, we have analyzed the clinical, prognostic and therapeutic data from cases diagnosed over the last 10 years at the Donostia University Hospital. The use of lenalidomide as treatment had many side effects in addition to positive ones, indicating that patient selection to use this drug should be carried out carefully. A treatment protocol is proposed in order to do so.

Keywords: MDS with isolated del(5q), 5q-syndrome, lenalidomide

Bidalia: 2018-05-17

Onartua: 2018-11-10

http://doi.org/10.26876/osagaiz.2.2018.171

\section{Sarrera}

Sindrome mielodisplasikoak hezur-muineko neoplasia klonal talde bat dira, hematopoiesi ezeraginkorra ezaugarritzat dutenak (1). Gaitz hematologiko talde horren barnean sindrome mielodiplasikoa del(5q) isolatuarekin sailkatzen da, eta SMD guztien \% 2,3 osatzen du (2).

Sindrome hau pairatzen duten paziente gehienak emakumeak izaten dira (gizon:emakume erlazioa 1:1,7 delarik) (2) eta batez beste 67 urteko adinarekin diagnostikatzen da (3).

5q- sindromean odol periferikoan anemia agertzen da nagusiki, gehienetan makrozitikoa dena. Sintomak honekin erlazionatuta egoten dira: nekea, ahultasuna, ariketa fisikoa egiteko zailtasuna, 
zorabioa edo kognizioaren nahasmendua. Plaketa kopurua normala edo altua izaten da. Tronbozitosia pazienteen herenean aurkitzen da eta tronbopenia ia inoiz ez (3). Odol periferikoan blastoen portzentajea < \% 1 da. Hezur-muina hiperzelularra edo normozelularra izan daiteke eta askotan eritroideen hipoplasia eritrozito kopurua gutxituta) egoten da. Megakariozitoak, plaketen jatorrizko zelulak, kopuru handituan egoten dira eta ohikoa izaten da tamaina txikiagoa izatea eta nukleo lobulatu gabeak edo hipolobulatuak izatea. Eritroideen lerroan eta mieloideen lerroan, berriz, displasia ez da horren ohikoa. Hezur-muineko blastoen portzentajea < \% 5 da (3). Ez da Auer makilarik egoten (3), beste sindrome batzuetatik desberdintzen laguntzen duena. Ezaugarri hauen eragilea 5. kromosomaren beso luzearen delezioa da. Delezio-gunea aldakorra da, ohikoenak del(5)(q13q31), del(5)(q13q33) eta del(5)(q22q33) izanik. Galera horietan guztietan maiz galtzen den gune bat dago: 5q31-q32, 1,5 Mb-ekoa, non 40 gene inguru kokatzen diren.

Diagnosia egiteko OMEren 2016ko irizpideak erabiltzen dira: lerro hematologiko batean, bitan zein hirutan displasia agertzea, zitopenia lerro batean edo bitan, eraztundun sideroblastoak hezurmuinean izatea edo ez, odol periferikoan blastoen portzentajea $<\% 1$ izatea, hezur-muinean $<\% 5$, Auer makilarik ez edukitzea, eta, azkenik, $5 q$ delezio isolatua izatea edo beste alterazio batekin, 7 . kromosomaren galera edo 7q delezioa izan ezik (1). Beraz, anemia errefraktarioa aurkezten duen paziente batean susmatuko dugu eta proba desberdinak erabiliko ditugu aurrekoa frogatzeko. Horien artean hemograma, hezur-muineko aspiratuarekin egindako mielograma eta zitometria, hezurreko biopsia eta kariotipoaren azterketa beharrezkoak dira. Gainera FISH, immunokimika eta beste proba batzuk ere erabil daitezke (4).

SMDa pairatzen duten pazienteen pronostikoa ezaugarri ezberdinen arabera sailkatzeko asmoz, 90 eko hamarkadan IPSS argitaratu zen. Ondoren, aurkikuntza berrien ildotik, WPSS eta IPSS-R bertsio errebisatuak eman dira ezagutzera. LMAra eraldatzeko eta hilkortasun-tasa aztertzen duten pronostiko-eskala horiek erabiliz, SMD del( $5 q)$ isolatuarekin pairatzen duten pazienteak arrisku baxukoak direla ikusi da eta mielodisplasia sindromeen artean pronostiko zein batez besteko biziraupen hoberenetarikoa dutela.

Sindrome honen biziraupenaren mediana 79 hilabetekoa da, bi urtetara biziraupen-portzentajea $\% 89$ da eta 5 urtetara \% 64 (8). LMAra eraldaketa-portzentajea \% 13,2koa da, bi urtetara \% 5 izanik eta 5 urtetara, berriz, \% $14(8)$.

Heriotzaren arrazoia gehienetan zitopeniak eta haien ondorioak izaten dira, hemorragiak eta infekzioak gehienbat. Horregatik, tratamenduarekin lortu nahi izaten da odol-zelula kontaketa hobetzea, bizi-kalitatea hobetzea, infekzioak bezalako konplikazioak gutxitzea eta transfusiobeharrak jaistea (2).

5q- sindromearen tratamenduan globulu gorrien transfusio errepikatuak erabiltzen dira. Eritropoietina (EPO) eta darbopoietina (DAR) ere erabili izan dira tratamenduan, granulozitoen kolonien faktore estimulatzaileekin (G-CSF) edo gabe (2). Lenalidomida da gaur egun 5qsindromearen tratamenduan indarrean dagoen farmako immunomodulatzailea. 2005. urtean onartu zuen farmako hori FDAk (US Food and Drug Administration) arrisku baxu edo bitarteko SMD 5q delezio isolatuarekin edo beste alterazio batzuekin duten eta gainera transfusio-mendekoak diren pazienteen tratamendurako (2). Lenalidomidaren eraginari esker batez beste 2 urteko eritroide transfusioarekiko independentzia lortzen da, erantzun zitogenetiko partzial edo osoa eta bizikalitatearen hobekuntza (9). Era berean, albo-ondorioak izan ditzake: neutropenia (\% 33-\% 61) eta tronbozitopenia (\% 19-\% 62), batez ere tratamenduaren lehen 6-8 asteetan, garrantzitsuena izanik. Pruritoa (\% 4-\% 42), rash-a (\% 19-\% 36), beherakoa (\% 17-\% 49), sakoneko tronbosi benosoa (\% 4$\% 10$ ) eta birika-tronboembolismoa (\% 2-\% 4) ere deskribatuak izan dira beste batzuen artean (9) (10). $10 \mathrm{mg}$ /eguneko 21 eguneko zikloetan hartzea $5 \mathrm{mg}$ /eguneko 28 eguneko zikloetan hartzea bezain segurua eta eraginkorragoa dela ikusi da (2). Droga hipometilatzaileak eta zitarabina (ARA-C) dosi baxuetan ez dira erabiltzen sindrome honen tratamenduan, eta hezur-muinaren transplantea ere ez da hasierako aukera terapeutikoa (2). 


\section{Material eta metodoak}

Lan hau egiteko lehenik eta behin sindrome honi buruzko informazio-bilaketa egin zen. Horretarako Uptodate datu-basea eta OMEren tumore hematopoietikoen liburua kontsultatu ziren. Donostia Unibertsitate Ospitalean OVID sisteman bilaketa bibliografiko bat egin zen honako gako-hitz hauek erabiliz artikuluak bilatzeko: MDS with isolated del(5q), 5q- syndrome, lenalidomide.

Kasuak bilatzeko Donostia Unibertsitate Ospitaleko Hematologia zerbitzuak 2008. urtetik aurrera duen mielogramen datu-basea erabili zen. Datu-base horretan 2017ko bukaera arte 5qsindromearen diagnosia zuten kasuak identifikatu, sindrome horretan deskribatzen diren ezaugarriekin bat zetozela ziurtatu eta kariotipo bateragarria zutela konprobatu zen. Gainera CLINIC programari esker pazienteen historia klinikoa irakurri eta OMEGA programarekin analitikak eta kariotipoa aztertu ziren.

Lortutako datu guztiak Excel taula batean bildu ziren eta programa horri esker batezbestekoak atera ziren, ondoren datuak literatura medikoarekin konparatu ahal izateko. Era berean taula desberdinak garatzeko erabili zen.

Azkenik biziraupenaren kalkulua egiteko eta irudia lortzeko Kaplan-Meier metodoa erabili zen MedCal programarekin.

\section{Emaitzak}

Donostia Unibertsitate Ospitalean 2008tik 2017rako epean mielogramaren bat egindako SMD del(5q) isolatu bezala diagnostikatutako 11 kasu aurkitu ziren ( 2 kasu lehendik diagnostikatuta zeuden eta kontrol-mielograma bat egin zitzaien epe horretan).

Pazienteen gehiengoa emakumezkoa izan zen, 8 emakume $(\% 72,72)$ eta 3 gizon $(\% 27,27)$, eta diagnosiaren uneko batez besteko adina 62 (38-84) urtekoa izan zen.

Sindrome honen diagnosia egiteko orduan egindako lehenengo hemograman 1. taulak jasotzen dituen emaitzak lortu ziren. Datu horiei erreparatuz paziente guztiek anemia zutela ikusi zen eta 7 kasutan $(\% 63,63)$ makrozitikoa zela. Plaketei dagokienez, gehienak balio normalen barruan zeudela ikusi zen, 10 pazientetan $(\% 90,90)$. Kasu bakarrak $(\% 9,09)$ zuen tronbozitosia, plaketa kopurua $490 \mathrm{x}$ $10^{9} / \mathrm{L}$ izanik. Leukozitoei erreparatuz hiru kasutan $(\% 27,27)$ agertu zen leukopenia eta gainontzeko zortziak $(\% 72,72)$ balio normalen barruan zeuden. Neutropenia paziente bakarrean $(\% 9,09)$ aurkitu zen eta odol periferikoan ez zen blastorik aurkitu.

Mielogramek (2. taula) hezur-muineko blasto kopurua kasu guztietan < 5 izan zela erakusten dute, diagnosirako beharrezkoa dena. Displasia lerro hematologiko desberdinetan aurkitu zen. 6 pazientek $(\% 54,54)$ diseritropoiesia zuten eta disgranulopoiesia, berriz, 4k (\% 36,36). Guztiek zuten dismegakariopoiesia megakariozito hipolobulatuekin (1. eta 2. irudiak). Eritroblastoen portzentajea balio normalen barruan zegoen 4 kasutan $(\% 36,36)$, 6k (\% 54,54) eritroblasto kopuru baxua zuten eta batek $(\% 9,09)$ handiagoa. Eraztundun sideroblastoak 3 pazienteren $(\% 27,27)$ mielogrametan ikusi ziren kopuru baxuan. 
Lide Ezenarro, Jose Ramon Furundarena, Anunciación Urquia

1. taula. Diagnopsirako unean egindako hemograman lortutako emaitzak.

\begin{tabular}{|ll|}
\hline Parametroa & Batezbestekoa (minimoa-maximoa) \\
\hline Hemoglobina $(\mathrm{g} / \mathrm{dL})$ & $9,52(6,3-10,8)$ \\
Hematokritoa $(\%)$ & $29,1(20,3-33,5)$ \\
BBK $(\mathrm{fL})$ & $106,53(90,2-123,4)$ \\
Plaketak $\left(\times 10^{9} / \mathrm{L}\right)$ & $254,81(167-490)$ \\
Leukozitoak $\left(\times 10^{9} / \mathrm{L}\right)$ & $5,07(1,27-8,08)$ \\
Neutrofiloak $\left(\times 10^{9} / \mathrm{L}\right)$ & $2,66(0,41-5,65)$ \\
Blastoak odol periferikoan $(\%)$ & $0(0-0)$ \\
\hline
\end{tabular}

2. taula. Diagnopsirako unean egindako mielogramako datuak.

\begin{tabular}{ll}
\hline Blastoak \% (minimoa-maximoa) & $1,99(0,3-3,6)$ \\
Displasia n(\%) & $6(\% 54,54)$ \\
$\quad$ Diseritropoiesia & $4(\% 36,36)$ \\
$\quad$ Disgranulopoiesia & $11(\% 100)$ \\
$\quad$ Dismegakariopoiesia & $11(\% 100)$ \\
$\quad$ Megakariozito hipolobulatuak & $18,97(8-45)$ \\
Eritroblastoak \% (minimoa-maximoa) & Eraztundun sideroblastoak \% (minimoa- \\
maximoa) & $0,63(0-3)$
\end{tabular}

1. eta 2. irudiak. SMD del(5q) isolatuarekin. Megakariozito hipolobulatuak.

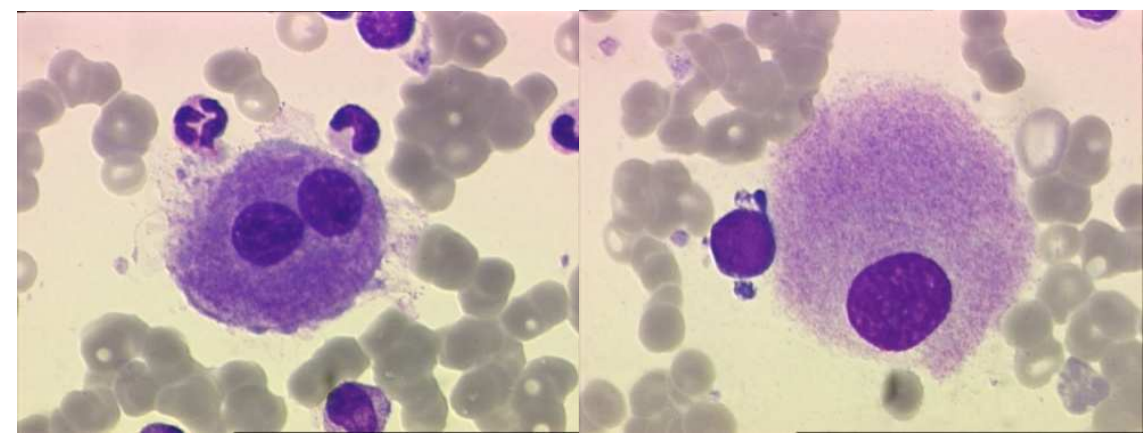

Diagnosirako beste urrats garrantzitsu bat zitogenetika da eta kariotipoa aztertuz kasu guztietan 5 . kromosomaren beso luzearen delezioa aurkitu zen. Paziente batean, diagnosiaren unean, $5 q$ delezioa FISH teknikarekin (sentsibilitate handiagoko teknika) bakarrik antzeman zen, baina aurrerago egindako beste kariotipo batean delezioa aurkitu zen. Batez beste, aztertutako metafaseen $\%$ 68,46an (\% 36,66-\% 100) ikusi zen $5 q$ delezioa.

Pronostikoa aztertzeko ohiko sailkapenak erabiliz, paziente guztiak arrisku baxuko taldeetan sailkatu ziren (3. taula). 
3. taula. SMD del $(5 q)$ isolatuarekin, sailkapen pronostikoen arabera banatuta.

\begin{tabular}{|cl|}
\hline IPSSn (\%) & $10(\% 90,90)$ \\
Baxua & $1(\% 9,09)$ \\
Bitartekoa-1 & $0(\% 0)$ \\
Bitartekoa-2 & $0(\% 0)$ \\
Altua & \\
IPSS-Rn (\%) & $1(\% 9,09)$ \\
Oso baxua & $9(\% 81,81)$ \\
Baxua & $1(\% 9,09)$ \\
Bitartekoa & $0(\% 0)$ \\
Altua & $0(\% 0)$ \\
Oso altua & \\
WPSSn (\%) & $2(\% 18,18)$ \\
Oso baxua & $9(\% 81,81)$ \\
Baxua & $0(\% 0)$ \\
Bitartekoa & $0(\% 0)$ \\
Altua & $0(\% 0)$ \\
Oso altua & \\
\hline
\end{tabular}

Tratamenduari dagokionez, diagnosiaren unean 5 pazientek $(\% 45,45)$ transfusioekiko dependentzia zutela ikusi zen, eta aurrerago 4 kasutan $(\% 36,36)$ agertu zen transfusioen beharra. Beraz, azken batean 9 pazientek $(\% 81,81)$ izan zuten transfusioekiko dependentzia. Diagnosia egin eta lehenengo transfusiora arte igarotako denboraren batezbestekoa 16,62 (0-51) hilabetekoa izan zen. Jarraipen osoan zehar transfusioak behar izan zituzten pazienteei transfunditutako unitateen batezbestekoa 16,87 (1-91) unitatekoa izan zen. Transfusioen eraginez burdin gainkarga gerta daiteke eta horrek albo-ondorioak izan ditzake. Horregatik 3 pazienteri $(\% 27,27)$ burdin kelatzailea (deferasirox) eman zitzaien, tranfusio gehien jaso zuten hiru pazienteei hain zuzen ere.

10 pazienteri (\% 90,90) EPO jarri zitzaien lehen aukera terapeutiko bezala. Horietako 4k (\% 40) diagnosiaren unetik transfusioak jaso zituzten, eta beste $4 \mathrm{k}(\% 40)$, hasiera batean behar ez izan eta EPOarekin tratatu arren, tranfusio-beharra garatu eta geroago transfusioak jaso behar izan zituzten.

Bi pazientek $(\% 18,18)$ tratamendu bezala transfusioak eta EPO bakarrik behar izan zituzten. Gainerako kasuetan lenalidomida farmako immunomodulatzailea erabili zen.

Sarreran aipatu bezala lenalidomida da sindrome honetan nagusiki erabiltzen den farmakoa eta 9 pazientek $(\% 81,81)$ hartu zuten. Gehiengoak, 8 pazientek $(\% 88,88) 21$ eguneko zikloak egin zituzten, egunero $10 \mathrm{mg}$ hartuaz. Paziente bakarrak $(\% 11,11) 21$ eguneko zikloak egin zituen, egunero $5 \mathrm{mg}$ hartuaz. Aurrerago azaltzen den moduan, bi kasutan (\% 22,22), albo-ondorioak zirela-eta, dosia $10 \mathrm{mg}$-tik $5 \mathrm{mg}$-ra jaitsi zen. Tratamendu honen helburu nagusia transfusioekiko independentzia lortzea da eta 5 kasutan $(\% 55,55)$ lortu zen. Era berean, erantzun zitogenetikoa bilatzen da lenalidomidarekin eta 4 pazientetan $(\% 44,44)$ lortu zen. Erremisio morfologikoa, aldiz, ez zen kasu bakar batean ere eman.

Lenalidomidak albo-ondorioak eragin ditzake eta 7 kasutan $(\% 77,77)$ deskribatu ziren. Larruazaleko toxikotasuna 4 pazientek $(\% 44,44)$ izan zuten eta rash eta prurito bezala agertu zen. Horietako kasu bat transfusioek eragindako burdin gainkargarekin erlazionatu zen eta burdin kelatzaile batekin tratatuz konpondu zen. Beste bi antihistaminikoekin kontrolatu ziren, eta kasu bakarrak lenalidomida tratamendua utzi zuen. Beste albo-ondorio bat biriketako tronboenbolismoa izan zen eta 3 pazientek $(\% 33,33)$ izan zuten. Horietako bik hilabete batzuetako geldialdia egin zuten tratamenduan eta besteak guztiz suspenditu zuten lenalidomida. Paziente batek $(\% 11,11)$ beheko gorputz-adarreko sakoneko tronbosi benosoa izan zuen eta beste batek azaleko tronboflebitisa. Bi kasu horietan ez zen lenalidomidaren tratamendua aldatu. Paziente batek $(\% 11,11)$ toxikotasun hepatikoa izan zuen eta, ondorioz, bi hilabetez tratamendua utzi behar izan zuen. Berriro hasterakoan dosia 5 mg-ra jaitsi zen. Neutropenia kasu bakarra $(\% 11,11)$ egon zen eta ziklo batez lenalidomida suspenditu zen. Azkenik, kasu batean $(\% 11,11)$ digestioaren nahasmendu zehaztugabeak deskribatu ziren eta beste paziente batean $(\% 11,11)$ bizkarreko mina, min prekordiala eta pilulak irensteko zailtasunak zirela-

$$
\text { Osagaiz - } 2018 \text { - 2. bolumena - 2. zk. }-29
$$


eta tratamendua bertan behera gelditu zen. Beraz, albo-ondorioak direla-eta, 2 kasutan $(\% 22,22)$ dosia jaitsi zen, 4 kasutan $(\% 44,44)$ tratamenduaren etenaldia egin zen ziklo batzuetan zehar eta 3 kasutan (\% 33,33) guztiz suspenditu zen.

Talde osoaren batez besteko jarraipena 69 hilabetekoa izan zen eta biziraupenaren mediana 59 (11191) hilabetekoa. 3. irudian biziraupenaren grafika ikusi daiteke.

3. irudia. SMD del(5q) isolatuaren diagnosia zuten kasuen biziraupenaren grafikoa.

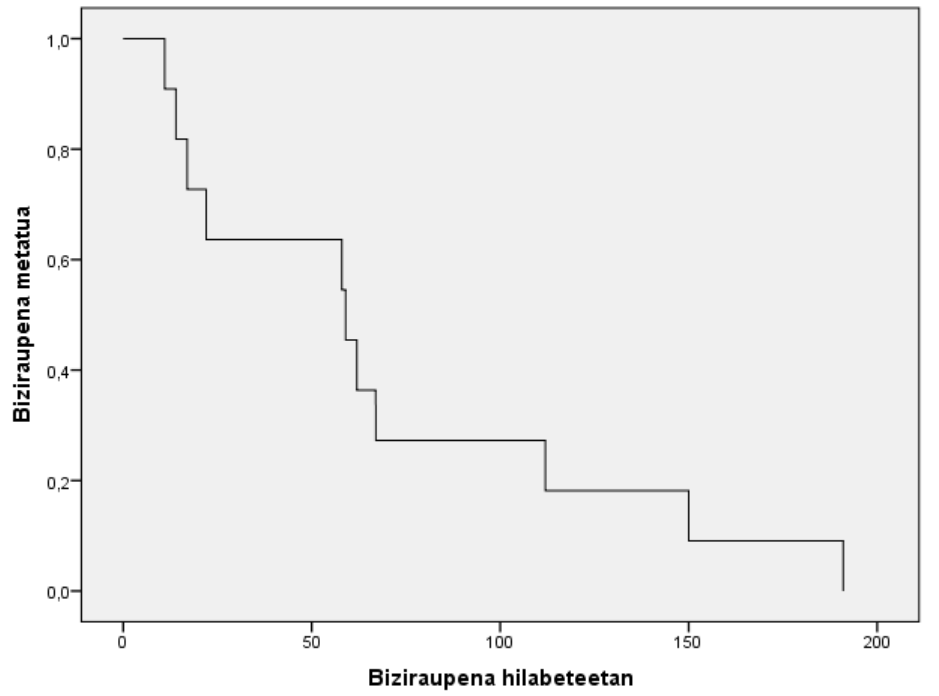

Lau kasu $(\% 36,36)$ eraldatu ziren: bi kasu $(\% 18,18)$ arrisku handiagoko SMD batera, hain zuzen, SMD gehiegizko blastoekin (SMD-GB) izatera pasa ziren, eta beste bi kasu $(\% 18,18)$ leuzemia akutu mieloide (LAM) batera eraldatu ziren.

Jarraipen-denboran hiru paziente $(\% 27,27)$ hil egin ziren: bat biriketako minbizi baten ondorioz hil zen, eta beste bietan ez zen ondo jaso heriotzaren arrazoia. Hala ere, horietako bat LAMera eraldatuta zegoen eta besteak SMD-GB-ren diagnosia zeukan heriotzaren unean.

\section{Eztabaida}

Donostia Unibertsitate Ospitalean SMD del( $5 q)$ isolatuaren diagnosia zuten kasuak aztertu ondoren, lortutako emaitzak literaturak dioenarekin alderatu ziren.

Azken hamarkadan sindrome hau izandako 11 pazienteei erreparatuta, gehiengoa emakumezkoa zela ikusi zen literaturan deskribitzen den bezala (2), eta diagnosiaren uneko adina ere antzekoa izan zen, hemengo batezbestekoa 62 urtekoa izanik eta orokorra 67 urtekoa izanda (3).

Arestian aipatu bezala, sindrome honetan hemograman aurkitzen den datu bereizgarrienetarikoa anemia da, gehienetan makrozitikoa dena (3). Anemia paziente guztietan aurkitu zen eta kasu gehienetan makrozitikoa izan zen. Plaketen maila normala izaten da, eta kasuen heren batean tronbozitosia egoten da (3). Aztertutako pazienteetan plaketa kopurua balio normalen artean zegoen kasu bakarrean izan ezik, zeinak tronbozitosia zuen. Tronbopenia ez da ohikoa izaten sindrome honetan (3) eta ez zen kasu bakar bat ere atzeman. Leukozitoetan eragin txikia izaten du SMD mota honek eta gure taldean hiru leukopenia $(\% 27,27)$ aurkitu ziren, eta horietako paziente batean neutropenia $(\% 9$,09). Odol periferikoko blasto kopuruari dagokionez, $<\% 1$ izan behar duela bete zen (3). 
Diagnosirako beharrezko diren beste datu batzuk mielogramak ematen ditu. Blastoak < \% 5 izan behar dira eta dismegakariopoiesia megakariozito hipolobulatuekin egoten da (3). Kasu guztietan aurreko biak bete ziren. Beste displasiak ez dira horren ohikoak izaten (3), baina zenbait kasutan disgranulopoiesia zein diseritropoiesia aurkitu ziren diagnosiaren uneko mielogrametan. Sindrome honen diagnosian eraztundun sideroblastoak egoteak edo ez, ez du garrantzirik eta ez da Auer makilarik egoten (3). Hain zuzen ere, ez zen Auer makilarik aurkitu eta eraztundun sideroblastoak hiru pazientetan aurkitu ziren portzentaje baxuan. Eritroblastoen portzentajeari dagokionez, lau kasutan balio normalen azpitik egon zen eta bakarrean gainetik. Sindrome honetan eritroideen lerroa kaltetzen da, eta ohikoa da eritroideen hipoplasia (3).

Alterazio zitogenetikoa egotea da diagnosirako behar den azken datua eta kasu guztietan aurkitu zen 5. kromosomaren beso luzearen delezioa. Paziente batean, diagnosiaren unean, $5 q$ delezioa FISH teknikarekin bakarrik antzeman zen, baina aurrerago egindako beste kariotipo batean delezioa aurkitu zen.

Sindrome honen definizioarengatik kasu guztietan bete zen sailkapen pronostiko desberdinak erabiliz arrisku baxuko taldetan sailkatzea (5) (6) (7).

Tratamenduari dagokionez, anemia kontrolpean mantentzeko EPOa erabili zen 10 pazientetan $(\% 90,90)$. Horietako 4k diagnosiaren unetik transfusioak jaso zituzten. Beste kasuetan ez zen hasiera batean beharrezkoa izan, baina ondoren anemia larriagotu eta transfusioak behar izan ziren. Kasu horietan transfusioen beharra atzeratzearen arrazoia izan liteke EPOa. Aurreragoko algoritmoan jasotzen da zein kasutan den egokia farmako honen erabilera (4. irudia).

Diagnosiaren unean 5 pazientek zuten transfusioekiko dependentzia, baina jarraipen-denboran guztira bederatzi pazientek behar izan zituzten transfusioak. Sindrome honetan anemia larria izaten da eta paziente gehienek transfusioak behar izaten dituzte, horregatik espero izatekoa zen paziente gehienek tratamendu horren beharra izatea lehenago edo beranduago. Diagnosiaren unean transfusio-dependentzia ez izatearen arrazoia anemia horren larria ez izatea edo EPO tratamenduarekin kontrolpean mantentzea izan zen.

Lehen transfusioa, batez beste, 16,87 hilabetera egin zen, literaturak deskribatzen duen 7,6 hilabete baino beranduago (2). Gure taldean transfunditutako batez besteko unitate kopurua 24koa izan zen, literaturan jasotzen den 83 unitateko batezbestekoa baino baxuagoa (2). Odol-unitate gutxiago transfunditzearen arrazoiak gure gaixo-taldearen jarraipena laburragoa izatea eta lenalidomidaren erabileragatik transfusioen beharra gutxitzea izan daitezke.

Lenalidomida arrisku baxua edo bitartekoa duten eta transfusioekiko dependentzia duten SMD kasuetarako onartua dago eta horien barne dago SMD del(5q) isolatuarekin (2). Transfusioekiko dependentziarekin amaitzea eta erantzun zitogenetikoa lortzea da farmako horren helburua (2). Aztertutako pazienteetan hala erabili zen, transfusioekin ondo kontrolatuta ez zeuden kasuetan eta transfunditutako unitate asko zeramatzatenetan. Transfusio-independentzia 5 kasutan lortu zen $(\% 55,55)$ eta erantzun zitogenetikoa, berriz, 4 pazientetan $(\% 44,44)$. Bestetik, albo-ondorioak 7 kasutan $(\% 77,77)$ deskribatu ziren. Larruazaleko toxikotasuna 4 pazientek $(\% 44,44)$ agertu zuten. Albo-ondorio hori ohikoa izaten da, literaturan pruritoa (\% 4-\% 42) eta rash-a (\% 19-\% 36) deskribatzen direlarik (10). Tronboenbolismo benosoaren lau kasu egon ziren, beheko gorputzadarreko sakoneko tronbosi benoso bat eta biriketako hiru tronboenbolismo. Lenalidomidak tronbosi benosoak eta arterialak eragin ditzakeela jakina da, baina literaturan agertzen den baino portzentaje handiagoan agertu dira gure kasuetan. Kontuan izan behar da paziente kopurua nahiko baxua dela $(n=11)$ eta, beharbada, lenalidomidarekin batera EPOa erabili izanak ere eragina izango zuen, ezaguna baita bi medikazioak batera erabiliz gero tronbosiaren arriskua oraindik eta gehiago handitzen dela. Halere, gaur egun ez dago indikatuta profilaxi antitronbotikoa kasu hauetan. Gaixo hauei oharrak eman behar zaizkie tronboenbolismoarekin lotura izan dezaketen sintomekin hasten baldin badira medikuari segituan esateko (10). Neutropenia, eragin desiragaitzen artean, gehien ematen dena (\% 33-\% 61) dela dio literaturak (10), eta kasu bakarrean agertu zen. Albo-ondorio 
horien eraginez, 2 kasutan (\% 22,22) dosia jaitsi zen, 4 kasutan $(\% 44,44)$ ziklo batzuetako etenaldia egin zen tratamenduan eta 3 kasutan $(\% 33,33)$ guztiz suspenditu zen.

Beraz, lenalidomidarekin lorturiko emaitza hauei erreparatuz gero, transfusio-independentzia eta erantzun zitogenetikoa lortu ziren arren, agerturiko eragin desiragaitzak ugariak izan ziren, eta tratamendua atzerarazi edo utzarazi zuten. Transfusioek dakartzaten komplikazio kliniko ugariak (burdin eta bolumen-gainkarga, infekzioak, aloimmunizazioa eta erreakzio alergikoak), bizikalitatearen okerragotzea eta inpaktu ekonomiko negatiboa (2) bezalako albo-ondorioak saihestu ziren, baina era berean, sintoma berriak agertu ziren. Horrela, lenalidomidak eragin positiboak izateaz gain, kaltegarriak ere badituela ikusi da eta argi gelditu da kontuz erabaki behar dela noiz erabili farmako hau.

Mielodisplasia sindromearen diagnosirako eta tratamendurako gida espainiarrak honako gomendio hauek ematen ditu lenalidomida erabiltzeko arrisku baxuko SMDetan: lenalidomida aukerakoa kontsideratzen da transfusio-dependentzia duten del(5q) sindromeetan, batez ere, EPOari erantzuteko probabilitatea eskasa denean edo arrakastarik izan ez duenean. $5 q-$-ren deleziorik gabeko kasu hautatu batzuetan ere erabil daiteke farmako hau. Gomendatutako dosia $10 \mathrm{mg} /$ egunekoa da 21 egunetan zehar, 28 eguneko zikloetan. Tratamendua gutxienez 3 zikloz mantendu behar da bertan behera uztea pentsatu aurretik, eta erantzunik lortu ezean, ez da 4 ziklo baino gehiago mantendu behar. Ez dago ondo zehaztuta tratamendua noiz arte luzatu behar den, erantzuna galdu arte edo okerrera egin arte. Toxikotasunak kontuan hartu behar dira, batez ere hematologikoak, eta horien funtsean dosia doitu behar da. Azkenik, erantzuna galduz gero, pazientea berriro aztertu beharra dago gaixotasuna eraldatzen ari den jakiteko (11).

Mielodisplasia sindromeen tratamendurik egokiena aukeratzeko protokolo desberdinak daude, eta jarraian dagoen 4. irudian, arrisku baxuko mielodisplasia sindromeetan erabil daitekeen algoritmo terapeutikoa proposatzen da (11).

4. irudia. Arrisku baxuko sindrome mielodisplasikoetan erabiltzeko algoritmo terapeutikoa (11). PMO: hezurmuinaren ziztada; AEE: eritropoiesiaren agente estimulatzaileak; AZA: azazitidina; TIS: tratamendu immunosupresorea; alo-TPH: aitzindari hematopoietikoen transplante alogenikoa.

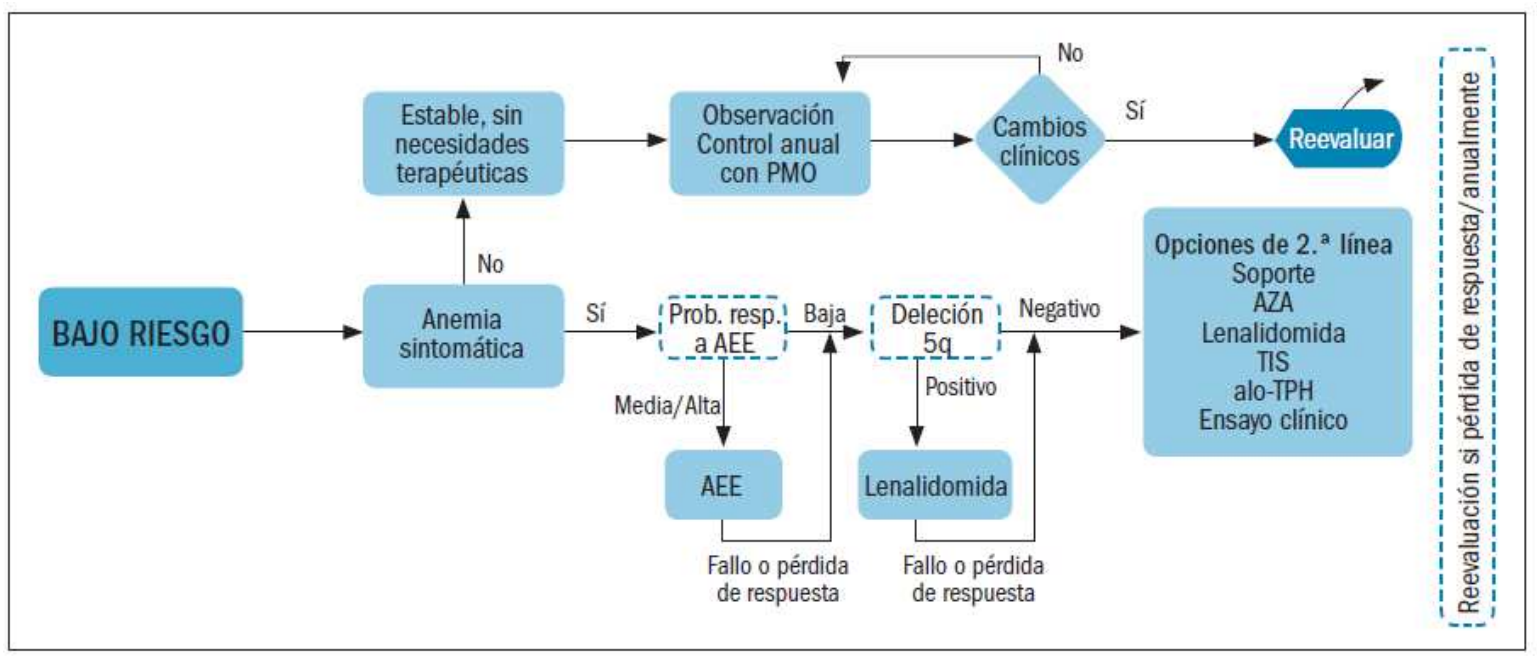

4. irudian ikusten den moduan, lehenik eta behin pazienteak tratamendurik behar duen erabaki behar da. Zitopenia larririk eta beste alteraziorik ez dagoenean, urteroko kontrolekin nahikoa izaten $\mathrm{da}$, eta aldaketa klinikoak egonez gero, birbaloratuko da. Anemia sintomatikoa dagoenean, berriz, aurretik esan bezala gehienetan anemia izaten da zitopenia ohikoena, lehenengo aukera terapeutikoa eritropoiesiaren agente estimulatzaileak (AEE) izaten dira (11). Transfusio-dependentzia eta serumeko eritropoietina maila kontuan hartzen dira tratamendu hau ezartzeko orduan, eta dosi

Osagaiz - $2018-2$. bolumena - 2. zk. -32 
altuekin hastea gomendatzen da, EPOaren kasuan 60.000-80.000 UI/asteko (11). 8-12 astetara erantzuna ebaluatzen da, 4 astetara hemograma egitea gomendatzen den arren, eta eritroideen erantzuna lortuz gero, dosia doitu egingo da hemoglobina $11-12 \mathrm{~g} / \mathrm{dL}$ artean mantentzeko (11). Garrantzitsua da hemoglobina $<12 \mathrm{~g} / \mathrm{dL}$ mantentzea, maila altuagoan egonez gero sakoneko tronbosi benosoaren arriskua handitzen baita. 5q- sindromean ere EPOa erabil daiteke, baina emaitzak apalagoak eta denbora gutxiagokoak izaten dira (12). 16-20 asteko epe batean erantzunik lortu ezean, erantzuna galduz gero edo hasiera batetik AEE-ei erantzuteko aukera baxua dagoela ikusiz gero, 5q-ren delezioa dagoen aztertuko da. Nahasmendu zitogenetiko hori agertuz gero, lenalidomida erabiliko da. 5q-ren deleziorik ez dagoenean, bigarren lerroko aukerak erabiltzen dira: mantentze-neurriak, azazitidina, lenalidomida, tratamendu immunosupresorea (TIS), alotransplantea edo entsegu klinikoak (11). Lenalidomida erabiltzen den kasuetan ez dela eraginkorra ondorioztatzen da 8-12 aste ondoren erantzunik lortzen ez baldin bada edo eritroideen erantzuna galtzen bada (13). Kasu horietan aipaturiko bigarren lerroko aukerak erabiltzen dira.

Batez besteko jarraipena 69 hilabetekoa izan zen eta biziraupenaren mediana 59 (11-191) hilabetekoa. Hori, deskribatuta dauden 79 hilabeteen azpitik dago (8), beharbada batez besteko jarraipena baxuagoa izateagatik.

Eraldaketa-portzentajea \% 36,36 izan zen, bi kasu $(\% 18,18)$ SMD-GB izatera pasa ziren eta beste bi kasu $(\% 18,18)$ LAM batera eraldatu ziren, LAM kasuetarako deskribatuta dagoen \% 13,2tik gertu $(8)$. Lau kasu horietako hiru lenalidomidarekin tratatzen ari ziren hezur-muineko blasto kopurua $>\% 5$ zela ikusi zenean. Pazienteetako batean bilakaera klonala agertu zenean, tp53 mutazioa aurkitu zen. Eraldaketa horiek zerk eragin dituen jakitea zaila da, baina lenalidomidak LMAera eraldatzeko arriskua ez duela handitzen ikusi da (14).

Heriotzaren arrazoiei dagokienez, gehienetan zitopeniek dakartzaten ondorioei lotzen zaiela esaten da (2). Azterketa honen jarraipen-denboran hiru paziente $(\% 27,27)$ hil ziren, bat biriketako minbizi baten ondorioz, eta beste bien kasuan ez zen ondo jaso heriotzaren arrazoia. Hala ere, horietako bat LAMera eraldatuta zegoen eta besteak SMD-GB diagnosia zeukan heriotzaren unean.

\section{Ondorioak}

Egindako azterketarekin Donostiako Unibertsitate Ospitalean SMD del(5q) isolatuarekin duten pazienteen kopurua txikia dela ikusi da. Kasu kopurua txikia izan arren, anemia errefraktarioen diagnosi diferentzialean kontuan hartu behar da. Literaturan deskribatzen den bezala, aztertutako kasuak pronostiko onekoak izan ziren. Tratamendurako EPOa, transfusioak eta lenalidomida erabili ziren, eta azkenekoak eragindako albo-ondorioen ugaritasuna aipagarria izan zen. Lenalidomidak eragin positiboak dituen arren, albo-ondorio ugari agertu zituen, beraz kontuz aukeratu behar dira farmako hori komenigarria izango zaien pazienteak, eta horretarako protokoloa proposatu da. Arrisku handiagoko SMD batera edo LAM batera eraldatzea zerk eragiten duen jakitera bideratutako ikerketa gehiago egitea izango litzateke hurrengo urratsa, horiek saihestu eta beharbada batez besteko biziraupena are gehiago luzatzeko.

\section{Oharra}

Euskal Herriko Unibertsitateko Medikuntza Graduan egindako gradu-amaierako lanean oinarritutako artikulua da. 


\section{Bibliografia}

1. Arber DA, Orazi A, Hasserjian R, Thiele J, Borowitz MJ, Le Beau MM, Bloomfield CD, Cazzola M, Vardiman JW. The 2016 revision to the World Health Organization classification of myeloid neoplasms and acute leukemia. Blood. 2016;127(20):2391-405.

2. Chavarri A, Massone R. Avances en los aspectos fisiopatológicos y terapéuticos del Síndrome $5 q$ menos. Hematología 2014; 18 (1):31-39.

3. R.D Brunning, A. Orazi, U. Germing, M.M. Le Beau. Myelodysplastic syndromes/neoplasms. Hemen: S.H. Swerdlow, E. Campo, N. Lee Harris, E.S. Jaffe, S.A. Pileri, H. Stein, J. Thiele, J.W. Vardiman (Eds.), WHO Classification of Tumours of Haematopoietic and Lymphoid Tissues. Lyon: IARC Press; 2008. or. 87-107.

4. Aster J.C., Stone R.M. Clinical manifestations and diagnosis of the myelodysplastic syndromes. 2017 [Eguneratuta: 2017-09-25; Kontsulta: 2017-10-01]. Hemen: Uptodate [Internet]. Waltham (MA): Uptodate. c2017. [22 or.]. Eskuragarri: https://www.uptodate.com/

5. Greenberg P, Cox C, LeBeau MM, Fenaux P, Morel P, Sanz G, Sanz M, Vallespi T, Hamblin T, Oscier D, Ohyashiki K, Toyama K, Aul C, Mufti G, Bennett J. International scoring system for evaluating prognosis in myelodysplastic syndromes. Blood. 1997;89(6):2079-88. Erratum in: Blood 1998;91(3):1100.

6. Greenberg PL, Tuechler H, Schanz J, Sanz G, Garcia-Manero G, Solé F, etal. Revised international prognostic scoring system for myelodysplastic syndromes.Blood. 2012;120(12):2454-65.

7. Malcovati L, Germing U, Kuendgen A, Della Porta MG, Pascutto $C$, Invernizzi R, Giagounidis A, Hildebrandt B, Bernasconi P, Knipp S, Strupp C, Lazzarino M, Aul C, Cazzola M. Time-dependent prognostic scoring system for predicting survival and leukemic evolution in myelodysplastic syndromes. J Clin Oncol. 2007;25(23):3503-10.

8. Strupp C, Nachtkamp K, Hildebrandt B, Giagounidis A, Haas R, Gattermann N, Bennett JM, Aul C, Germing U. New proposals of the WHO working group (2016) for the diagnosis of myelodysplastic syndromes (MDS): Characteristics of refined MDS types. Leuk Res. 2017;57:7884.

9. Kelaidi $C$, Eclache $V$, Fenaux $P$. The role of lenalidomide in the management of myelodysplasia with del 5q. Br J Haematol. 2008;140(3):267-78. doi: 10.1111/j.1365-2141.2007.06910.x.

10. Lenalidomide: Drug information. 2017. [Kontsulta: 2017-10-01]. Hemen: Uptodate [Internet]. Waltham (MA): Uptodate. c2017. [22 or.]. Eskuragarri:https://www.uptodate.com/

11. Valcárcel D, Bonanad S, García R, Remacha A, Bernal T, Arrizabalaga B, De Paz R, Font P, Gómez E, González B, Sánchez-García J, Mora A, Andreu R, Orts M, Pérez-Rus G, Sancho E, Villegas A, Luño E, Sanz G, Cervera J, Florensa L, Xicoy B, Díez-Campelo M. Tratamiento de los síndromes mielodisplásicos de bajo riesgo. Haematologica. 2012; 97, supl. 5:27-32.

12. Valcárcel D, Merchán B. Diagnóstico Hemaológico integrado. Unidad 2; Subunidad 2.3: Presente y futuro de los sindromes mielodisplásicos. Vall d'Hebron Institute of Oncology.

13. Talati C, Sallman D, List A. Lenalidomide: Myelodysplastic syndromes with del(5q) and beyond. Semin Hematol. 2017;54(3):159-166. doi: 10.1053/j.seminhematol.2017.06.003.

14. Kuendgen A, Lauseker M, List AF, Fenaux $P$, Giagounidis AA, Brandenburg NA, Backstrom J, Glasmacher A, Hasford J, Germing U; International Working Group on MDS with del(5q). Lenalidomide does not increase AML progression risk in RBC transfusion-dependent patients with Low- or Intermediate-1-risk MDS with del(5q): a comparative analysis. Leukemia. 2013;27(5):1072-9. 